AJChE 2013, Vol. 13, No. 1, 1-10

\title{
Effects of Vacuum Drying on Structural Changes of Banana Slices
}

Wannapit Junlakan *,1

Ram Yamsaengsung ${ }^{1}$

Supawan Tirawanichakul ${ }^{1}$

${ }^{1}$ Department of Chemical Engineering, Faculty of Engineering Prince of Songkla University, Songkhla 90110 Thailand.

*e-mail : wannapit_@hotmail.com

The objective of this research was to study the optimum condition for the vacuum drying of banana slices using a vacuum dryer and to find out the appropriate thin layer equation for predicting the drying kinetic of bananas. The experiments were carried out at the drying temperatures of $60,70,80$ and $90^{\circ} \mathrm{C}$ and absolute chamber pressure of 30 $\mathrm{mmHg}$. The drying experiments were performed until the samples moisture content was lower than $3.4 \%$ (w.b.). Next, the dried products were analyzed for physical quality (in terms of color, shrinkage, and texture) and sensory quality (in terms of color, texture, flavor, crispness and overall acceptability). These data were used in choosing the optimum condition for the vacuum drying of banana slices.

From experimental results, the drying time at the highest drying temperature was the shortest. At this condition, the dried banana slices showed the highest degree of yellowness, lower shrinkage, and more crispness compared to lower drying temperatures. From sensory analysis, each drying condition showed significant effect on consumer acceptability with the drying temperature of 70,80 and $90^{\circ} \mathrm{C}$ showing the levels of the overall acceptability sensory qualities of dried banana is not significantly different. Consequently, the drying temperature of $90^{\circ} \mathrm{C}$ was suggested as the best drying condition for sliced bananas. Moreover, three mathematical models (Newton, Logarithmic and Page) describing thin layer drying were investigated. It was found that the thin layer equation providing the highest coefficient of determination $\left(R^{2}\right)$ and the lowest chi-square $\left(X^{2}\right)$ and root mean square error (RMSE) was the Logarithmic equation.

Keywords: Color, Sensory quality, Shrinkage, Texture, Vacuum drying

\section{INTRODUCTION}

Snack foods such as potato chips, tortilla chips, onion rings and banana chips are normally fried with vegetable oil, which provides crispness after processing. However, fried products raise major concerns by conscious consumers due to its oil content. To avoid this drying can effectively be utilized. There are many drying techniques available to dry products, but the most common technique is hot air drying. However, hot air drying yield a non-crisp product because its moisture content cannot be reduced to the desired value. Moreover the dense structure created due to its shrinkage, 
makes the product not crispy. Therefore, this process may not be an appropriate technique for producing a snack for which the crisp texture is preferred (Thuwapanichayanan et al. 2012). Vacuum drying is another process in which products are dried in a reduced pressure environment. That lowers the heat required for rapid drying. The lower pressures allow drying temperature to be reduced and higher quality to be obtained compared to the traditional methods (Jaya and Das 2003).

Fresh bananas perish rapidly after harvesting and appropriate technology is generally applied to extend its shelf life. Drying extends the shelf-life of a food product because a lack of water prevents microorganisms from growing (Benedict et al. 1958).

\section{EXPERIMENTAL}

\section{Materials and Methods}

A schematic diagram of the vacuum dryer used in the present study is shown in Figure 1. The experimental setup consisted of a vacuum dryer, a condenser and a liquid ring vacuum pump (Model ET32030, Nash, Trumbull, CT).The vacuum dryer was constructed from stainless steel with a diameter of $400 \mathrm{~mm}$, a height of $300 \mathrm{~mm}$, and a wall thickness of $6 \mathrm{~mm}$. The stainless steel lid of the dryer had a thickness of 8 $\mathrm{mm}$. The condenser was fabricated and assembled by the Department of Chemical Engineering, Faculty of Engineering Prince of Songkla University, Hat Yai, Thailand. The condenser consisted of a $9425 \mathrm{~mm}$ long stainless steel tube with an internal diameter of $19 \mathrm{~mm}$ coiled inside a stainless steel container circulated with cooling water. The vacuum pump was purchased from Kinetics Engineering Co. (Thailand) (Yamsaengsung et al. 2011). The vacuum dryer was preheated for approximately 1 hour until the selected drying temperature was reached. Drying experiments were conducted at temperatures of 70, 80 and $90^{\circ} \mathrm{C}$, and an absolute chamber pressure of

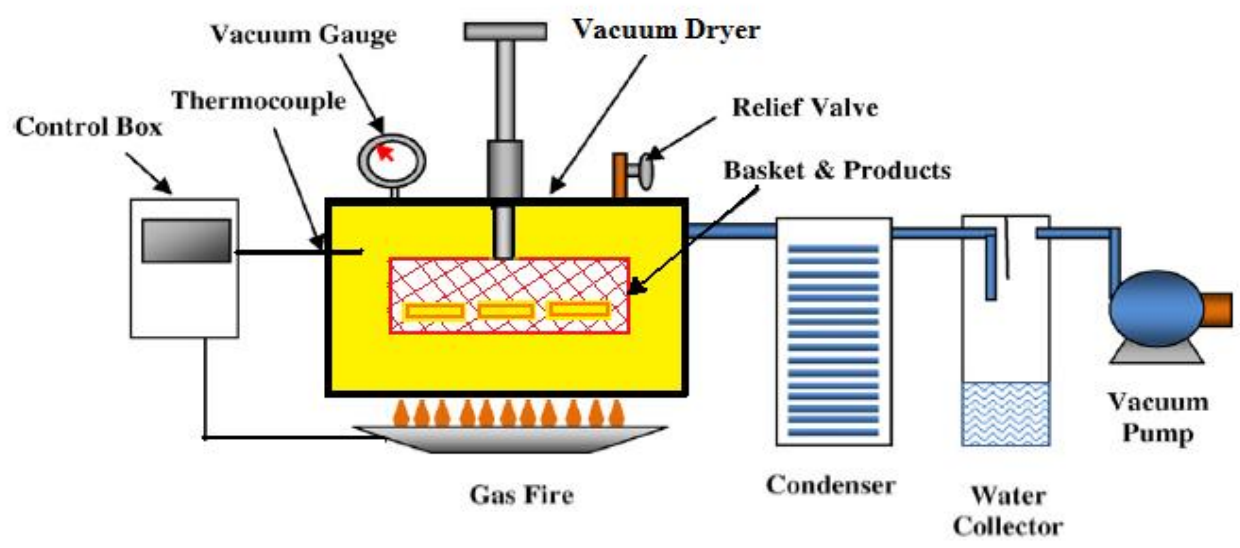

Fig. 1: Schematic diagram of vacuum drying system: consisting of a vacuum dryer, a condenser, a liquid ring vacuum pump (Model ET32030, Nash, Trumbull, CT). The vacuum dryer was constructed from stainless steel with a diameter of $400 \mathrm{~mm}$, a height of $300 \mathrm{~mm}$, and a wall thickness of $6 \mathrm{~mm}$. The stainless steel lid of the dryer had a thickness of $8 \mathrm{~mm}$. (Yamsaengsung and Rungsee 2003). 
$30 \mathrm{mmHg}$. The fresh bananas were placed on the wire netting basket and dried in each experiment. The moisture contents of the dried samples were continuously calculated at intervals of $30 \mathrm{~min}$. The drying experiments were performed until the final moisture content reached $3.4 \%$ (w.b.). All experiments were performed in triplicate.

Fresh bananas (cultivated in Songkhla Province, Thailand, cultivar: Gros Michel banana or 'kuauyhomtong' in Thai) were purchased from a local market. A ripeness level of green tip (color index no. 5) was used in this study (Nimmol et al. 2007). The fresh bananas had an initial moisture content in the range of $73.36-73.39 \%$ (w.b.) change to $3.4 \%$ (w.b.). The bananas were peeled and sliced using a blade to 2.50-3.50 $\mathrm{mm}$ thick. The diameter of the bananas was in the range of $31.50-34.50$ $\mathrm{mm}$.

\section{Evaluation of drying qualities}

The physical qualities of banana slices evaluated were color, shrinkage and texture in term of crispness and hardness. The colors of the samples were measured using a Hunter Lab color system colorimeter (Juki Model JP100, Japan). The color measurement of the samples in each condition was performed by using ten samples and the average value was reported. The color values of dried samples were compared with those of fresh samples and the normalized color changes were then calculated by the following equation (Swasdisevi et al. 2007):

$$
\begin{aligned}
& \frac{\Delta L}{L_{0}}=\frac{L-L_{0}}{L_{0}}, \frac{\Delta a}{a_{0}}=\frac{a-a_{0}}{a_{0}} \text {, and } \\
& \frac{\Delta b}{b_{0}}=\frac{b-b_{0}}{b_{0}}
\end{aligned}
$$

Due to the expansion of the dried banana slice resulting in a difficulty to measure and analyze shrinkage in terms of the percentage change of the volume of the sample. Therefore, in this study was to determine the drying shrinkage in terms of the percentage change of the crosssectional area of the sample. The drying shrinkage of the dried sample was calculated by the following equation (Yamsaengsung et al., 2011):

$$
\% \text { Shrinkage }=\left(\frac{A_{0}-A}{A_{0}}\right) \times 100
$$

The crispness and hardness of the final product was verified using a Texture Analyzer (Micro Stable, TA. XT. Plus, UK) fitted with a cutting probe (the guillotine) connected to a $1 \mathrm{~kg}$ load cell. The test implicated a Warner Bratzler or knife blade to cut the sample while measuring the maximum number of peaks (over $50 \mathrm{~g}$ of the force threshold). The cutting probe was set to move at a crosshead speed of $2 \mathrm{~mm} / \mathrm{s}$ until it cracked the sample (Nimmol et al. 2007).

\section{Sensory Analysis}

To evaluate the acceptability of the product, a nine point hedonic scale test for likeness was used (Peryam and Girardot 1952, Peryam and Pilgrim 1957, Yamsaengsung et al. 2011). Thirty panelists were used in this study (graduate students of the Department of Chemical Engineering, Prince of Songkla University, Songkhla, Thailand). Results of the sensory evaluation were statistically analyzed using a one-way analysis of variance (ANOVA). Test for significant difference at 95\% confidence interval $(p<0.05)$. 


\section{Mathematical modeling}

The moisture ratio (MR) of each sample during drying and the drying tare of the sample were determined by the following equations:

$$
\begin{aligned}
& M R=\left(\frac{M_{t}-M_{e}}{M_{0}-M_{e}}\right) \\
& \text { Drying rate }=\frac{M_{t}-M_{t+d t}}{d t}
\end{aligned}
$$

Drying curves (MR vs. time) were plotted and fitted by three empirical drying models (i.e., Newton's model, logarithmic model and Page's model). To select the best model for describing the drying curve in the process of drying the thin layer drying equations in Table 1 were tested. Model coefficients were calculated using STATISTICA software. The goodness of fit was evaluated by the coefficient of determination the regression $\left(R^{2}\right)$, the root mean square error (RMSE) and the mean square of the deviations between the experimental and calculated values for the models or chi square $\left(X^{2}\right)$ defined by the following equation 5 and 6 . The best model describing the vacuum drying process of the banana slices samples was chosen as the one with the highest $R^{2}$ and the least RMSE, $X^{2}$ (Zakipour and Hamidi 2011).

$$
R M S E=\left[\frac{1}{N} \sum_{i=1}^{N}\left(M R_{\text {pre }, i}-M R_{\text {exp }, i}\right)^{2}\right]^{\frac{1}{2}}
$$

$$
x^{2}=\frac{\sum_{i=1}^{N}\left(M R_{p r e, i}-M R_{\text {exp }, i}\right)^{2}}{N-n}
$$

\section{Statistical Analysis}

A duplicate of the entire experiments and the mean values with standard deviations were reported. The experimental data were analyzed using an analysis of variance (ANOVA). Duncan's multiple range test was used to establish the multiple comparisons of the mean values; mean values were considered at $95 \%$ confidence level $(p=0.05)$. A statistical program SPSS (SPSS software for Windows, release 15.0, SPSS Inc., USA) was used to perform all statistical calculations (Yamsaengsung et al. 2011).

\section{RESULTS AND DISCUSSION}

\section{Effect of Vacuum Drying Conditions on Drying Process}

After vacuum drying, the moisture content of the banana samples was reduced from a initial value of $73.3 \%$ (w.b.) to less than $3.4 \%$ (w.b.). The effects of drying temperature on the vacuum drying process are shown in Figure 2., in which drying curves (moisture ratio vs. time) under different drying conditions were plotted. From Figure 2, the drying time needed to reach the EMC was shortened notably with an increase in drying temperature due to a larger driving force

Table 1. Selected thin-layer drying models for describing drying curve.

\begin{tabular}{llll}
\hline Model number & \multicolumn{1}{c}{ Model equation } & \multicolumn{1}{c}{ Name } & \multicolumn{1}{c}{ References } \\
\hline 1 & $\mathrm{MR}=\exp (-\mathrm{kt})$ & Newton & O'Callaghan et al. 1971 \\
2 & $\mathrm{MR}=\mathrm{a} \exp (-\mathrm{kt})+\mathrm{c}$ & Logarithmic & Yagcioglu et al. 1999 \\
3 & $\mathrm{MR}=\exp \left(-\mathrm{kt} \mathrm{n}^{\mathrm{n}}\right)$ & Page & Page 1949 \\
\hline
\end{tabular}




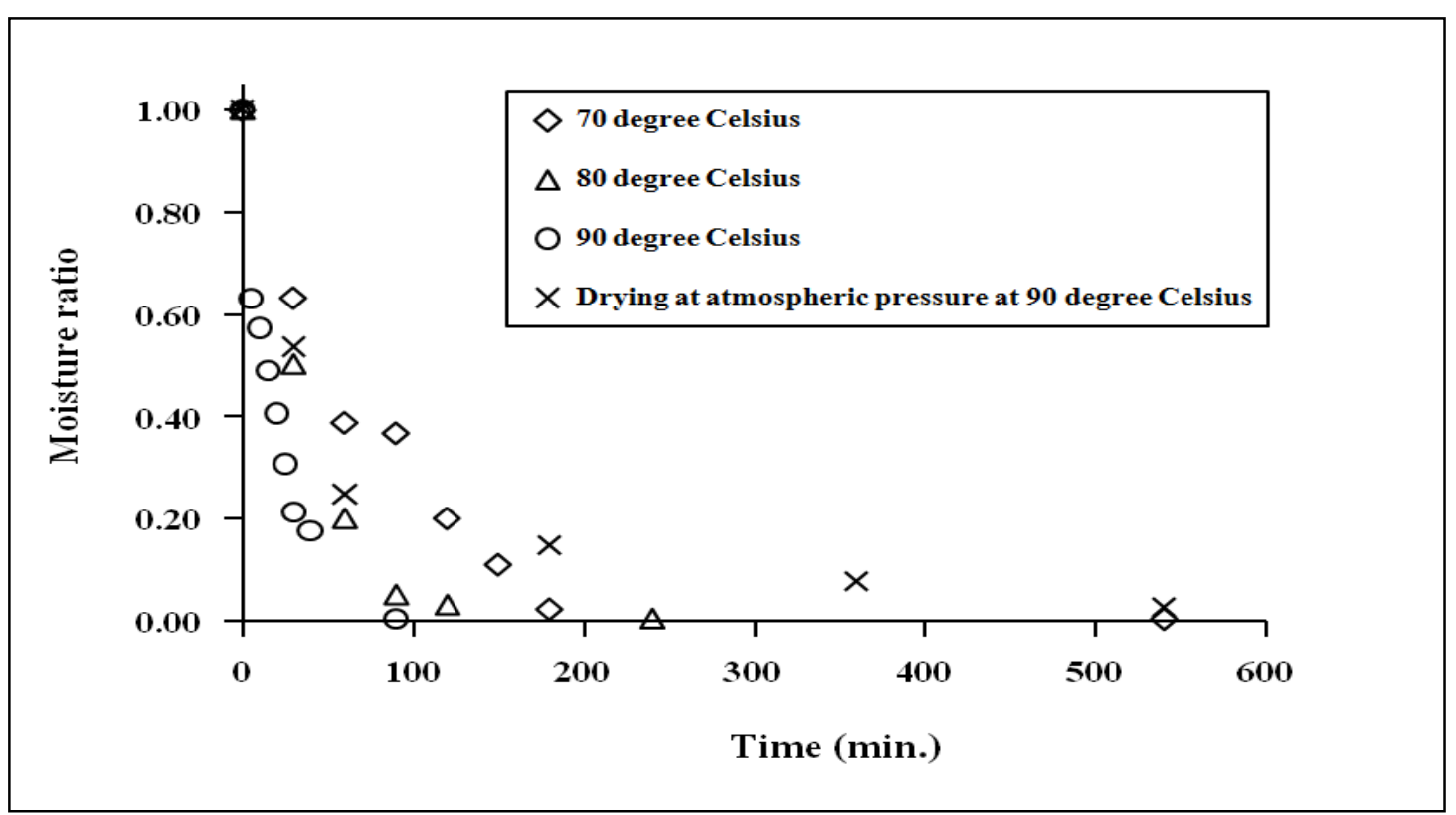

Fig. 2: Vacuum drying curves of bananas at different drying temperatures and drying methods at $30 \mathrm{mmHg}$ and a constant sample thickness of $2.5-3.5 \mathrm{~mm}$.

for heat and mass transfer at higher drying temperature. The research shows that the temperature difference affects the boiling point elevation of plasma concentrations of the materials tested. And it was found that the longer drying times were observed for the samples undergoing hot air drying. This is due to the existence of the condensation period and the lower evaporation rate of hot air drying than that of vacuum drying at these conditions (Methakhup et al. 2005).

\section{Qualities of Dried Banana Slices}

As shows in Table 2, the color changes of banana slices undergoing various banana surface temperatures. It was found that drying temperature of dried bananas did not significantly affect lightness of the dried products, while redness and yellow of dried bananas at $90^{\circ} \mathrm{C}$ were significantly higher than those dried at 70 and $80^{\circ} \mathrm{C}$. This is due to browning reaction occurring during drying process. Chua et al. (2002) reported that the different color of dried

Table 2. Color change of banana slices.

\begin{tabular}{llll}
\hline Temperature $\left({ }^{\circ} \mathrm{C}\right)$ & $\Delta L / L_{0}$ & $\Delta a / a_{0}$ & $\Delta b / b_{0}$ \\
\hline 70 & $-0.16 \pm 0.03^{\mathrm{a}}$ & $2.64 \pm 0.72^{\mathrm{a}}$ & $0.02 \pm 0.02^{\mathrm{a}}$ \\
80 & $-0.18 \pm 0.03^{\mathrm{a}}$ & $3.24 \pm 0.83^{\mathrm{ab}}$ & $0.02 \pm 0.02^{\mathrm{a}}$ \\
90 & $-0.18 \pm 0.02^{\mathrm{a}}$ & $3.59 \pm 0.36^{\mathrm{b}}$ & $0.10 \pm 0.04^{\mathrm{b}}$ \\
\hline
\end{tabular}

*Mean \pm SD.

${ }^{a-b}$ In the same column with different superscripts means that the values are significantly different (P $<0.05$ ). 
Table 3. Shrinkage of banana slices.

\begin{tabular}{ll}
\hline Temperature $\left({ }^{\circ} \mathrm{C}\right)$ & $\%$ Shrinkage \\
\hline 70 & $40.41 \pm 4.24^{\mathrm{a}}$ \\
80 & $39.46 \pm 5.69^{\mathrm{a}}$ \\
90 & $31.44 \pm 4.81^{\mathrm{b}}$ \\
\hline
\end{tabular}

*Mean士SD.

a-b In the same column with different superscripts means that the values are significantly different $(P$ $<0.05)$.

fruits under various drying conditions shows that temperature and duration of drying affects significantly browning reactions that occur during drying, lower drying temperature resulted in better color retention than drying at higher temperatures.

Table 3 shows the shrinkage of the banana slices under different drying conditions. It was found that shrinkage of dried products at 70 and $80^{\circ} \mathrm{C}$ were significantly higher than that of samples dried at $90^{\circ} \mathrm{C}$. Wu et al. (2007) for eggplants, Yan et al. (2008) for banana, pineapple and mango, Panyawong \& Devahastin (2007) and Swasdisevi et al. (2007) for bananas reported that the shrinkage was the least at the highest temperature of drying, similar tendency were also observed of this result.

Methakhup et al. (2005) reported that the high temperature was caused the temperature difference affects the boiling point elevation of plasma concentrations of the materials tested. This is due to the existence of the condensation period and the lower evaporation rate of hot air drying than that of vacuum drying at these conditions. Swasdisevi et al. (2007) also observed that the high temperature for a short period of time, which allows some amounts of moisture inside the food vaporizing suddenly. The product surface was dried. Since hardening occurred at the surface of the product, it helps maintain the shape of the dried fruit. So, the high shrinkage value increased with decreasing surface temperature.

Table 4 shows the hardness (Maximum force) and crispness (Number od peaks) of the products at different temperatures of drying. From Table 4, it was found that the hardness of dried bananas at $70^{\circ} \mathrm{C}$ were significantly higher than that of samples

Table 4. Effects of drying temperature on hardness (maximum force) and crispness (number of peaks) of dried bananas.

\begin{tabular}{lll}
\hline Temperature $\left({ }^{\circ} \mathrm{C}\right)$ & Maximum force $(\mathrm{N})$ & Number of peaks \\
\hline 70 & $53.16 \pm 7.08^{\mathrm{c}}$ & $32.29 \pm 5.41^{\mathrm{a}}$ \\
80 & $43.08 \pm 8.85^{\mathrm{b}}$ & $44.56 \pm 8.93^{\mathrm{b}}$ \\
90 & $33.56 \pm 6.35^{\mathrm{a}}$ & $53.29 \pm 8.90^{\mathrm{b}}$ \\
\hline
\end{tabular}

*Mean士SD.

a-c In the same column with different superscripts means that the values are significantly different ( $P$ $<0.05)$. 
dried at 80 and $90^{\circ} \mathrm{C}$. Thuwapanichayanan et al. (2012) reported that the low temperature drying for a long period of time was caused the dense structure in product due to its shrinkage. In addition, this table show the crispness of samples dried at $90^{\circ} \mathrm{C}$ were significantly higher than that of samples dried at 80 and $70^{\circ} \mathrm{C}$. Thuwapanichayanan et al. (2012) also revealed that the internal vapor pressure may have increased and this forces the food structure to be expanded, thereby producing the porous structure of food products. These result were similar to Thomkapanich (2006) who also found that of the vacuum drying for banana; the hardness of dried products increased with decreasing temperatures and the crispness of dried products increased with increasing temperatures.

In this study, the hardness and crispness of the dried bananas varied from $33.56 \pm 6.35$ to $53.16 \pm 7.08 \mathrm{~N}$ and $32.29 \pm 5.14$ to $53.29 \pm 8.90$ peaks, respectively. The hardness and crispness were compared with those of a commercially available bananas. The hardness and crispness of the commercially available freeze dried bananas (fruit King $^{\mathrm{TM}}$ ) (Nimmol et al. 2007) were $55.72 \pm 5.48 \mathrm{~N}$ and $16 \pm 3$ peaks, respectively. The result is that all the dried bananas in this study were lower values of hardness over the commercially available freeze dried bananas. Also, the dried banana slices in this study were higher values of crispness over the commercially available freeze dried bananas

\section{Sensory Analysis}

Table 5 shows the color, texture, flavor, crispness and overall acceptability of dried banana. The results showed that the drying temperature of 70,80 and $90^{\circ} \mathrm{C}$ showing the levels of the overall acceptability sensory qualities of dried banana is not significantly different. Overall acceptability for dried product was in the range of $6.12 \pm 0.24$ to $6.65 \pm 0.93$, which was an acceptable rate of consumers.

\section{Modelling of drying characteristics}

In this study, drying curves (MR vs. time) under various drying conditions were

Table 5. Sensory evaluation based on bananas at $30 \mathrm{mmHg}$ at different temperatures of drying.

\begin{tabular}{llllll}
\hline $\begin{array}{c}\text { Temperature } \\
\left({ }^{\circ} \mathrm{C}\right)\end{array}$ & \multicolumn{1}{c}{ Color } & \multicolumn{1}{c}{ Texture } & Flavor & Crispness & $\begin{array}{c}\text { Overall } \\
\text { acceptability }\end{array}$ \\
\hline 70 & $6.12 \pm 0.27^{\mathrm{a}}$ & $6 \pm 0.33^{\mathrm{a}}$ & $6.24 \pm 0.30^{\mathrm{a}}$ & $5.65 \pm 0.34^{\mathrm{a}}$ & $6.12 \pm 0.24^{\mathrm{a}}$ \\
80 & $6.59 \pm 0.27^{\mathrm{a}}$ & $6.53 \pm 0.30^{\mathrm{a}}$ & $6.29 \pm 0.35^{\mathrm{a}}$ & $6.29 \pm 0.31^{\mathrm{a}}$ & $6.59 \pm 0.30^{\mathrm{a}}$ \\
90 & $6.18 \pm 0.95^{\mathrm{a}}$ & $6.41 \pm 0.87^{\mathrm{a}}$ & $6.41 \pm 0.94^{\mathrm{a}}$ & $6.47 \pm 1.46^{\mathrm{a}}$ & $6.65 \pm 0.93^{\mathrm{a}}$ \\
\hline
\end{tabular}

*Mean \pm SD.

a In the same column with different superscripts means that the values are significantly different $(P$ $<0.05)$. 
Table 6. Modeling of moisture ratio according to drying time for banana slices.

\begin{tabular}{llrrr}
\hline \multicolumn{1}{c}{ Models } & \multicolumn{1}{c}{ Coefficients } & $\mathrm{R}^{2}$ & $\mathrm{X}^{2}$ & RMSE \\
\hline Newton & $\mathrm{k}=0.049917$ & 0.9734 & 0.0022 & 0.0496 \\
Logarithmic & $\mathrm{a}=0.950058, \mathrm{k}=0.042973, \mathrm{c}=-0.025276$ & 0.9795 & 0.0017 & 0.0434 \\
Page & $\mathrm{k}=0.074205, \mathrm{n}=0.880132$ & 0.9779 & 0.0018 & 0.0451 \\
\hline
\end{tabular}

plotted and fitted to the selected thin-layer drying models listed in Table 1 . The results of statistical analyses undertaken on these models for banana slices are given in Table 6. It was found that thin layer equation providing the highest $R^{2}$ and the lowest $X^{2}$ and RMSE was the Logarithmic equation. From the table, $\mathrm{R}^{2}, \mathrm{X}^{2}$ and $\mathrm{RMSE}$ values were $0.9795,0.0017$ and 0.0434 , respectively.

\section{CONCLUSIONS}

From experiments results, the drying time at the highest drying temperature was the shortest. At this condition, the dried banana slices showed the highest degree of yellowness, lower shrinkage, and more crispness compared to lower drying temperature. From sensory analysis, each drying condition shown the levels of the overall acceptability sensory qualities of dried banana is not significantly different. Consequently, the drying temperature of $90^{\circ} \mathrm{C}$ was suggested as the best drying condition for sliced bananas. Moreover, three mathematical models (Newton, Logarithmic and Page) describing thin layer drying were investigated. It was found that thin layer equation providing the highest coefficient of determination $\left(R^{2}\right)$ and the lowest chi-square $\left(X^{2}\right)$ and root mean square error (RMSE) was the Logarithmic equation.

\section{NOMENCLATURE}

$A_{0} \quad$ : initial cross sectional area of a banana sample $\left(\mathrm{mm}^{2}\right)$

$A \quad$ : final cross sectional area of a banana sample $\left(\mathrm{mm}^{2}\right)$

$a_{0} \quad$ : initial values of the redness of the sample prior to drying

$A \quad$ : redness of the dried sample

$b_{0} \quad$ : initial values of the yellowness of the sample prior to drying

$B \quad$ : yellowness of the dried sample

$L_{0} \quad$ : initial values of the lightness of the sample prior to drying

$L \quad$ : lightness of the dried sample

$M_{e} \quad$ : equilibrium moisture content (kg moisture/kg dry matter)

$M_{0} \quad$ : initial moisture content $(\mathrm{kg}$ moisture/kg dry matter)

$M R_{\text {exp }, i}$ : experimentally observed moisture ratio

$M R_{\text {pre }, i}$ : predicted moisture ratio

$M_{t} \quad$ : moisture content at $\mathrm{t}(\mathrm{kg}$ moisture/kg dry matter)

$M_{t+d t} \quad$ : moisture content at $\mathrm{t}+\mathrm{dt}(\mathrm{kg}$ moisture/kg dry matter)

$N \quad$ : number of observations

$n \quad$ : number constants

$t \quad$ : drying time (min) 


\section{REFERENCES}

1. Benedict, R. G., Corman, J., Sharpe, E. S., Kemp, C. E., Hall, H. H., and Jackson, R. W. (1958). Preservation of Microorganisms by Freeze-Drying. Journal of Applied Microbiology, 6, 401407.

2. Chua, K. J., Chou, S. K., Ho, J., Mujumdar, A. S., and Hawlader, M. N. A. (2002). Heat pump drying: Recent developments and future trends. Drying Technology, 20, 1579- 1610.

3. Jaya, S., and Das, H. A. (2003). A Vacuum Drying Model for Mango Pulp. Drying Technology An International Journal, 21, 1215-1234.

4. Methakhup, S., Chiewchan, N., and Devahastin, S. (2005). Effects of drying methods and conditions on drying kinetics and quality of Indian gooseberry flake. Journal of Food Science and Technology, 38, 579-587.

5. Nimmol, C., Devahastin, S., Swasdisevi, T., and Soponronnarit, S. (2007). Drying and heat transfer behavior of banana undergoing combined low-pressure superheated steam and far-infrared radiation drying. Journal of Applied Thermal Engineering, 27, 2483-2494.

6. Nimmol, C., Devahastin, S., Swasdisevi, T., and Soponronnarit, S. (2007). Drying of banana slices using combined lowpressure superheated steam and farinfrared radiation. Journal of Food Engineering, 81, 624-633.

7. Panyawong, S., and Devahastin, S. (2007). Determination of deformation of a food product undergoing different drying methods and conditions via evolution of a shape factor. Journal of
Food Engineering, 78, 151-161.

8. Peryam, D. R., and Girardot, N. F. (1952). Advanced taste-test method. Journal of Food Engineering, 24, 58-61, 194.

9. Peryam, D. R., and Pilgrim, F. J. (1957). Hedonic scale method of measuring food preferences. Journal of Food Technology, 11, 9-14.

10. Swasdisevi, T., Devahastin, $S$. , Ngamchum, R., and Soponronnarit, S. (2007). Optimization of a drying process using infraredvacuum drying of Cavendish banana slices. Songklanakarin Journal of Science and Technology, 29, 809-816.

11. Thomkapanish, O. (2006). Study of intermittent low-pressure superheated steam and vacuum drying of banana. M.Eng thesis, Department of Food Engineering, King University of Technology Thonburi.

12. Thuwapanichayanan, R., Prachayawarakorn, S. and Soponronnarit, S. (2012). Effects of foaming agents and foam density on drying characteristics and textural property of banana foams. Journal of Food Science and Technology, 47, 348357.

13. Wu, L., Orikasa, T., Ogawa, Y., and Tagawa, A. (2007). Vacuum drying characteristics of eggplants. Journal of Food Engineering, 83, 422-429.

14. Yamsaengsung, R., Ariyapuchai, T., and Prasertsit, K. (2011). Effects of vacuum frying on structural changes of bananas. Journal of Food Engineering, 106, 298-305.

15. Yamsaengsung, R., and Rungsee, $C$. (2003, October). Vacuum frying of fruits and vegetables. 13th Annual 


Conference of Thai Chemical
Engineering and Applied Chemistry, Nakhon Nayok, Thailand.

16. Yan, S. H., Yin, Y. P., Li, W. Y., Li, Y., Liang, T. B., Wu, Y. H. Geng, Q. H., and Wang, Z. L. (2008). Effect of high temperature after anthesis on starch formation of two wheat cultivars differing in heat tolerance. Acta Ecologica Sinica, 28, 6138-6147.

17. Zakipour, E., and Hamidi, Z. (2011). Vacuum Drying Characteristics of Some Vegetables. Iranian Journal of Chemistry and Chemical Engineering, 30, 97-105. 